\title{
インクジェットのレーザ観測と階調画像再生
}

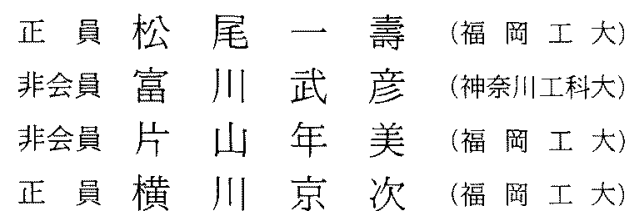

\section{Laser Observation and Tone Reproduction of Ink Jet}

Kazuhisa Matsuo, Member (Fukuoka Institute of Technology), Takehiko Tomikawa, Non member (Kanagawa Institute of Technology), Toshimi Katayama, Non-member, Kyouji Yokogawa, Member (Fukuoka Institute of Technology)

The ink flight of electrostatically extracted ink jet was observed by $\mathrm{He}-\mathrm{Ne}$ laser and an Application of this ink flight to tone reproduction is also described in this paper. Dielectric ink was used.

Ink is presumed to be in flight in the form of liquid thread at the nozzle tip and ink corpuscules beyond the region of ink thread. A liquid thread means a continuous flow of ink. In the region beyond the zone of liquid thread, ink corpuscules are generated randomly.

He-Ne laser made possible phtographing both an ink thread and the transition of ink jet beyond it in a picture. In analysis of the ink flight, the spread of ink and transition of ink jet were clarified by image processing concretely. Furthermore, we have proved that this transition of ink jet can be applied to tone reproduction.

キーワード：静電誘引形インクジェット、誘電性インク, He- Neレーザ光, 階調画像再生

\section{1. まえがき}

本諭文は，静電誘引形インクジェットの誘電性イン クを用いた曳系抒よび电采先端以降から分離してイン ク微粒子となって飛翔する現象（曳系の状態遷移：仮 称）の観測と，その現象に着目した階調画像の再生八 の応用について述心たものである。従来，インタジェ ットのインク飛稳は, 高速度写真, ストロボスコープ などを利用した，顕微鏡による写真撮影の力法が用い られていた ${ }^{(1)(2)}$ 。しかし，これらは焦点深度が浅く， 三次元的に飛翔しているインクジェットの写真撮影を するには難点があった。更に，ノズル先端からのイン ク飛翔は周期性を有している必要がある。

静電誘引形インクジェットの誘電性インクによるイ ンク飛翔は，ノズル先端の近傍加ら曳采領域，霧化領 域, 散乱領域八と遷移しているものと考えられる。
著者らは，このようなインク飛翔を电系の状態遷移 と呼んでいる。ここで曳糸領域は，連続流のインタ液 柱を意昧する。史系の長さは印加電圧またはインク静 圧の制御により変化する。霧化領域は, 曳系先端以降 に扔いて分離したインク微粒子が空間的にある程度均 一な範囲内に存在しているものと考文られる。また， 散乱領域は, 霧化領域の更に先端に执いて, 空気抵 抗，重力などの影響を強く受けて，乱流状態になって いると思われる。なお，霧化領域および散乱領域にお けるインクの飛叛は周期性を有してない。このような 史系の状態遷移は,インクの飛翔する過程に混在して いる。

従って, 曳系の状態遷移の写真撮影は, 従来の方法 では园難である。

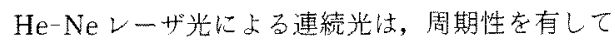
ないインク飛翔状海の写真攝影を可能とした ${ }^{(3)}$ 。

電学論 $C, 112$ 卷 9 号, 平成 4 年 
た，この方法は，ノズル先端から記録紙の位置に至る インク飛翔の全過程を, フィルムの一画面上に平均的 な全体像として撮らえることが可能である。 $\mathrm{He}-\mathrm{Ne}$ レーザ光による写真撮影妁，印加電圧やインク静圧 (インク液面の高さ）などを制御した場合，インク飛 翔のインク広がり具合や，电亲の状態遷移領域などへ の解析を有利にするものと考无られる。また，曳系の 状態僄移する現象が，階調画像再生人の応用の可能性 について検討した。一般にインクジェットを利用した 階調画像の再生はインク微粒子の個々を带電させて, 偏向電極により偏向量を制御する方式，インク微粒子 径を画像の湽淡に応じて制御する方式などが報告され ている(4)(5)

一方，Hertzらは，同一インク微粒子徍を同一位置 に重对打ちして階調を記録することを試みてい $3^{(6)(7)} c$

以上の方式は，インク微粒子を精密に制御する必要 があり，困難さを伴う。著者らは，静電誘引形インク ジェットの誘電性インクを用いた曳系の状態遷移を応 用した階調画像再生方法について検討した ${ }^{(8)}$

ノズル先端から一定距離にある記録紙の位置におけ るインク微粒子の付着状態を制衔することは，曳系長 を制御することに置き換えて考えることができる。

自然画像心有寸る階調特性を損わずに再生する場 合，高濃度の領域に対しては曳系を利用することがて きる。また，低濃度の領域に対しては曳系先端以降に おいて，ほぼ一定の範囲内に記録される霧化（微粒 子）領域を利用するものである。階調画像を再生する 場合は，大別して前記の二つの領域を利用することに より可能と思われる。静電誘引形インクジェットの誘 電性インクによる曳糸の状態遷移を階調画像再生入応 用した例はまだ試みられていない。

階謂画像の再生への試みは，比較的制御方法の簡単 な印加電圧の制御により行った。

\section{He-Ne レーザ光によるインク飛翔観測 装置}

$\mathrm{He}-\mathrm{Ne}$ レーザ光による静電誘引形インクジェット のインク飛翔状況を写真撮影するための装置の概要を 図1に示す。He-Ne レーザ光は，レンズ $L_{1} ， L_{2}$, $L_{3} ， L_{4}$ を介してフィルム面またはTV力メラに入射 する。ここで，He-Neレーザ光は，レンズ $L_{2}$ 掠よ び $L_{3}$ の間において平行光を構成している。この詳細 な光学系安図 2 に示す。

静電誘引形インクジェットの発生装置は，レンズ $L_{3}$ の前焦点位置 $f_{1}$ あたりに設け，後焦点位置 $f_{1}$ には

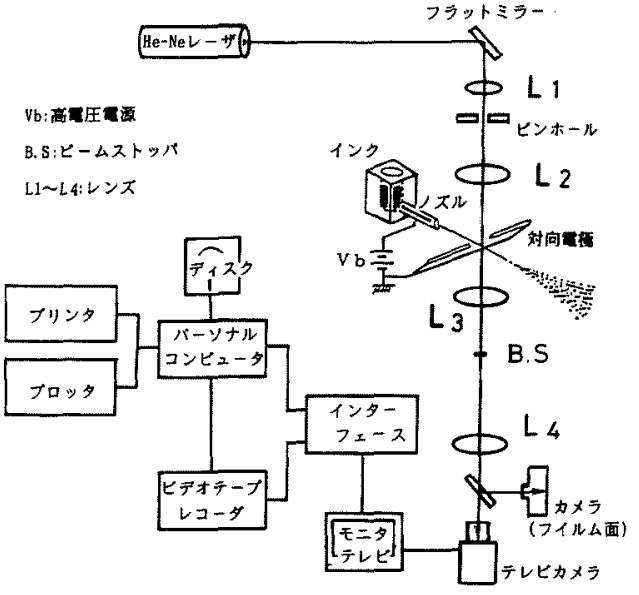

図 1 静電誘引形インクジェットの $\mathrm{He}-\mathrm{Ne}$ レーザ光によるインク飛翔観測装置

Fig. 1. Experimental overall system by $\mathrm{He}-\mathrm{Ne}$ laser.

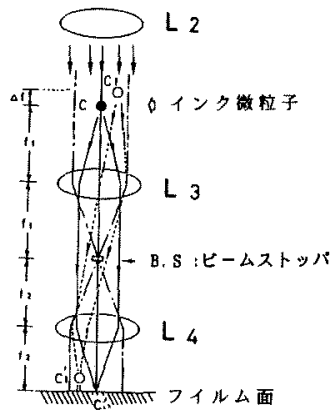

図 2 インク飛翔観測における光学系の詳細図

Fig. 2. Details of observation of flying ink.

レンズ $L_{3}$ に集光した平行光を遮るためのビームスト ッパ（B.S）を設けた。このような光学系を構成する ことにより，インク微粒子の散乱情報光のみがレンズ $L_{4}$ の焦点位置 $f_{2}$ であるフイルム面に暗視野散乱像と して記録される。

インク微粒子の飛翔軌跡は，He-Neレーザ光によ る連続光で撮影することで可能となる。この場合，物 体側焦点面上のインク微粒子は高強度の点像として記 録されるが焦点面から外れるほど，低強度で広がった 像となる。この方法は，ある時間内のインク微粒子の 飛跡を攝影することができる。He-Neレーザ光によ る観測は，インクジェット飛翔状沅を全体像として撮 らえるのに最適な方法であると思われる。静電誘引形 
インクジェット方式において，特に霧化された領域を 階調画像再生に応用する試みに扔いて，最適なインク 飛翔の観測方法であると考える。

\section{3. 静電誘引形インクジェットの実験装置}

\section{〈3・1〉静電誘引形インクジェットの発生方法}

静電誘引形インクジェットのインク飛判原理を図 3 に示寸。インク液面の高さによるインク静死を加える ことにより，ノズル先端にインクメニスカスを形成す b。

インクは，ノズルー対向電極間に電圧を印加すると 飛翔する。インク自身の直流バイアス電王 $V_{b}$ をノズ ルに印加している。画像の濃度情報を電気信号に変換 した画像信号電圧 $V_{s}$ を制御信号として対向電極に印 加した。インクは，その差電圧による静電誘引力によ り誘引され飛翔し, 紙面へ付着する。本方式は, /ズ ル内径に対して $1 / 100$ 程度の果系径を得ることができ ること，インク加圧機構や循環系が不要なことなどの 特徴を有する。他方式では, ノズル内径の約 2 倍程度 の直径をもったインク微粒子を発生している。またノ ズル径は，細くなる咶ど，ノズルの目づまりを生じき すくなるなどの問題を有している。本方式は，太いノ ズル径にもかかわらず細い曳系径在得ることが可能で ある。

〈3.2〉階調画像再生の実験装置 実験装置の概 要を図 3 に示す。入力画像デー夕は，TV力メラより $256 \times 256$ 画素 (pel) として, 同一画像デー夕を 4 回 入力した平均値をとっている。この画像データを $\mathrm{AD}$ 変換器により $8 \mathrm{bit} / \mathrm{pel} の$ 濃度情報としてフロッピー ディスクに格納した。今回は，ノズルの形状として， 外径 $680 \mu \mathrm{m}$, 内径 $380 \mu \mathrm{m}$, 長さ $15 \mathrm{~mm}$ のステンレ 又鋼製ハイイプを用いた。
ノズルの先端は，インクの応答性を高めるために中 心線と $30^{\circ}$ の角度に切断されている。対向電極㤝， ， ズルの先端から $2 \mathrm{~mm}$ 隔てて, 直径 $0.8 \mathrm{~mm} の$ 棒状電 極間を $3 \mathrm{~mm}$ の間隔を設けて，ノズルとは直角方向と して同一直線上に配置した。この対向電極には画像信 号電圧 $V_{s}$ が印加されている。従って, インクは2本 の棒状電極の $3 \mathrm{~mm}$ の中心を飛翔することになる。対 向電極から更に $1 \mathrm{~mm}$ 隔てて, 外径 $70 \mathrm{~mm}$ のドラム を設け、これを接地した。

良って，ノズルと刘向電極間に泣 $\left(V_{b}-V_{s}\right)$ の差電 玨が印加される。インクは、この差電在によるクーロ ン力に基づいて飛翔する。なお，画像信号電珐 $V_{s} は$ DA 変換器により出力され刘向電極に印加される。記 録方法は，ドラムに記録紙を巻付けて行われる。な お，記録は主走查方向にドラムを用いて，パルスモー タで制御した。また，副走査方向に対してはノズルへ ッド部をリニアパルスモータで制䘖した。画像データ として,ファクシミリテストチャートNo.1（画像電 子学会)による濃淡の女性像を用いた。

\section{4. 実験結果}

〈4・1〉曳糸の状態遷移における記録例 ノズルー 記録紙間の距離を変化させたときの記録例を図 4 に示 す。この例では，記録紙を手走查により一定方向に引 張って記録し，顕微鏡（×100）により写真撮影した

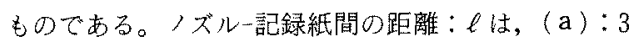
$\mathrm{mm}$, (b) $: 5 \mathrm{~mm}$, (c) $: 7 \mathrm{~mm}$, (d) $: 10 \mathrm{~mm}$ 々 徐々に遠ざけた。

記録紙に対するインクの付着状態は，ノズルの先端 から記録紙の位置を遠ざけるに従って線状で記録され ていたものが，やがて分散して広範囲に記録されるよ うになる。曳糸の状態䢩移する現象はこのように記録

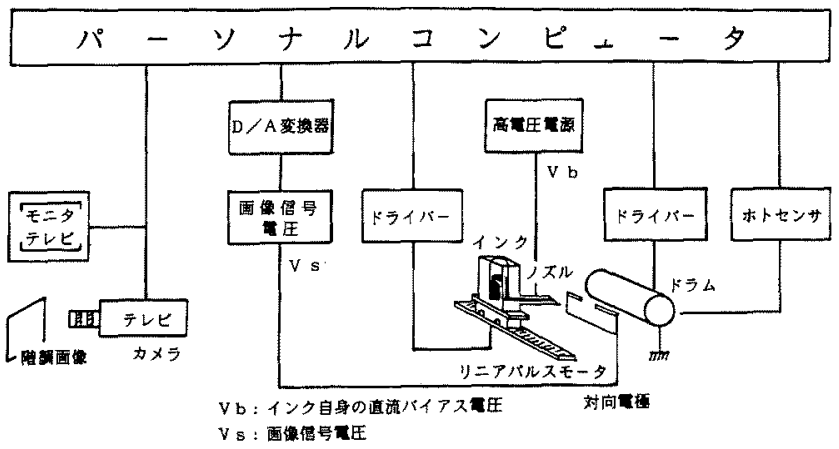

図 3 静電誘引形インクジェットによる階調画像再生装置

Fig. 3. Experimental overall system by electrostatically extracted ink jet.

笔学論C, 112 巻 9 号, 平成 4 年 
(a)

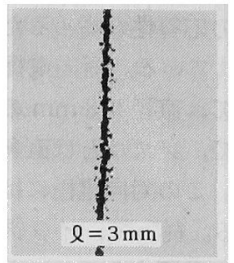

(c)

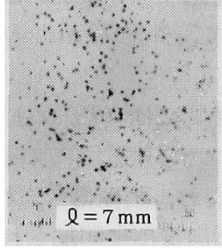

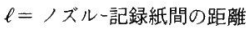

(b)

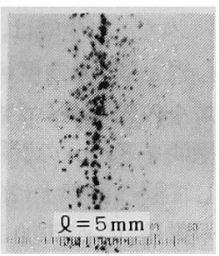

(d)

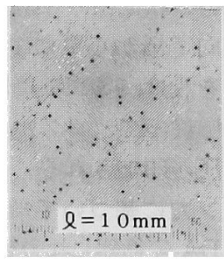

$1 \mathrm{~m} \mathrm{~m}$

図 4 静電誘引形インクジェットの記録例

Fig. 4. Example of recordings by ink jet.

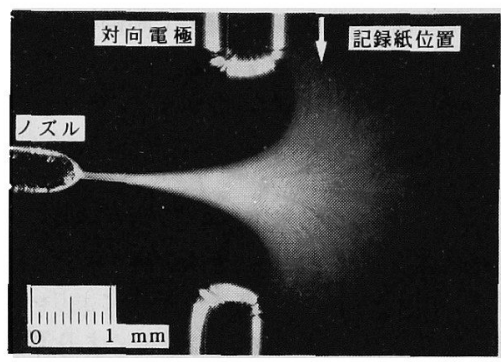

(a) $V_{1}=2.5 \mathrm{kV}$

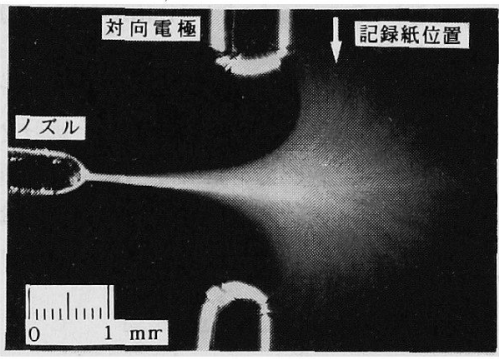

(c) $V_{3}=2.7 \mathrm{kV}$

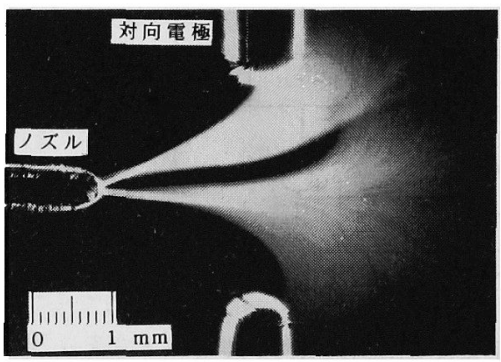

(e ) $V_{5}=2.9 \mathrm{kV}$

紙の位置を変化させることでも理解される。

〈4・2〉印加電圧を制御した場合の He-Ne レーザ

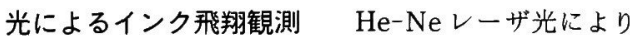
写真撮影 $(1 / 30 \mathrm{~s})$ された静電誘引形インクジェット のインク飛翔例を図 5 に示す。インクは, ノズル先端 の近傍において細い曳系となって飛翔するが，対向電 極を通過したのち，きれいな銀杏の葉状（扇形）とな り飛散していることが判明された。測定条件は，イン ク静圧 $H=5 \mathrm{~mm}$ 一定として印加電圧を変化させた。 印加電圧は， $V_{1}=2.5 \mathrm{kV}$ で安定なインク飛翔状態を 示した。インク飛翔の全体像は, 印加電圧を $V_{2}=2.6$ $\mathrm{kV}$ から $V_{4}=2.8 \mathrm{kV}$ へと高くするに従って，ノズル 先端より右方向(記録紙の位置)へ伸びていることが理 解される。曳系は, 印加電圧の制御により曳系長が変 化する。これは一般に, 導電率 $10^{-10} 1 / \Omega \cdot \mathrm{m}$ 前後の非

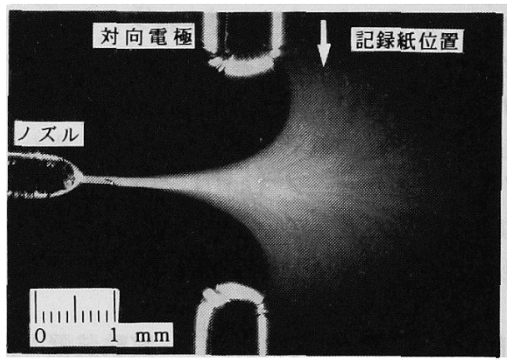

(b) $V_{2}=2.6 \mathrm{kV}$

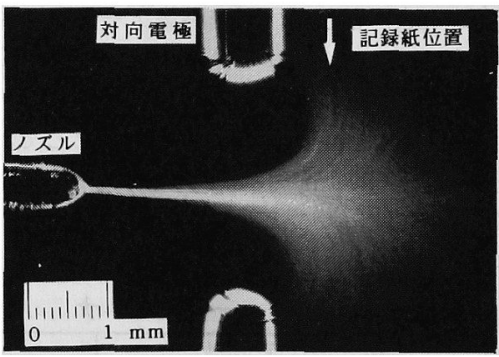

(d) $V_{4}=2.8 \mathrm{kV}$

図 5 静電誘引形インクジェットの $\mathrm{He}-\mathrm{Ne}$ レーザ光によるインク飛翔観測 (インク静圧 $H=5 \mathrm{~mm}, 1 / 30 \mathrm{~s}$ )

Fig. 5. Observation of flying ink by $\mathrm{He}^{-}$ Ne laser (ink pressure $H=5 \mathrm{~mm}, 1 / 30 \mathrm{~s}$ ). 


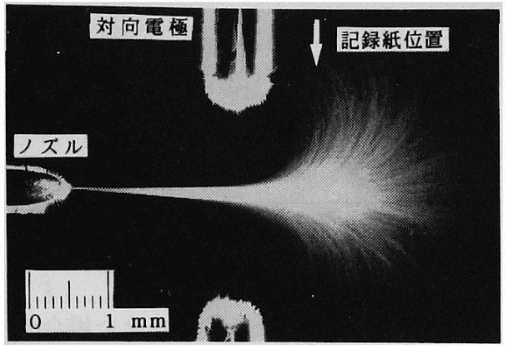

(a) $\quad V_{1}=2.5 \mathrm{kV}$

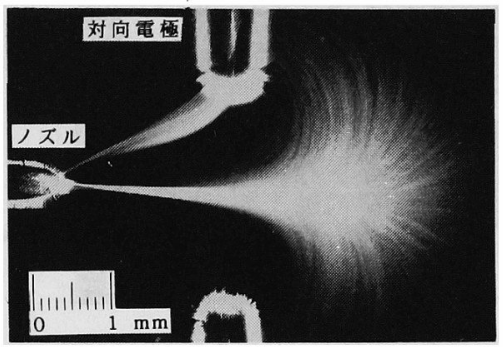

(b) $V_{5}=2.9 \mathrm{kV}$

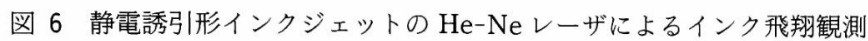
(インク静圧 $H=10 \mathrm{~mm}, 1 / 30 \mathrm{~s}$ )

Fig. 6. Observation of flying ink by $\mathrm{He}-\mathrm{Ne}$ laser (ink pressure $H=10 \mathrm{~mm}, 1 / 30 \mathrm{~s}$ ).

水系液体において曳采長は印加電圧により変化し，そ の極大值が存在することによるものと考えられる(9)。 また, 印加電圧が $V_{5}=2.9 \mathrm{kV}$ になると複数本のイン ク飛翔が見られるようになる。

これは, 対向電極の位置, 形状, 空間電荷の分布状況, インク液面の表面張力の不均一, インクの物性值, ズル先端の研磨の状態など様々な要因が考えられる。

階調画像再生は, ノズル-対向電極間の印加電圧を 安定なインク飛翔開始電圧から複数本のインク飛翔に 至らない印加電圧の範囲でなければならない。

また，He-Neレーザ光に対してノズルおよび対向 電極の位置を $90^{\circ}$ 回転させ, インクの飛翔を試みて写 真撮影を行った。その, インク飛翔状況に特別な差異 は観測されなかった。従って, ノズル先端から飛翔す るインクは, 対向電極を通過する近辺から霧化状とな り, 円錐状に飛散していることを示している。

〈4・3〉インク静圧を制御した場合の $\mathrm{He}$ - Neレー ザ光によるインク飛翔観測 インク静圧を制御させ たときの静電誘引形インクジェットによるインク飛翔 状況の写真撮影 $(1 / 30 \mathrm{~s})$ 例を図 6 に示す。同図は, 印加電圧 $V=2.5 \mathrm{kV}$ および $2.9 \mathrm{kV}$ として, インク 静圧を $H=10 \mathrm{~mm}$ としたときのインク飛翔例を示す。 インク飛翔状況は, 図 5 (a) と図 6 (a) の同一の印加 電圧で比較すると，インク静圧が高くなるほど記録紙 の位置方向へ伸びている。インク飛翔状況の形状自身 は, 図 5 と基本的に変化ないものと思われる。

このように, 曳系長はインク静圧の制御によっても 変化する。これは，ノズル先端のインクメニスカスの 曲率半径を変化させ, インク流量の増減が曳系長に影 響を与えるものと考えられる。インク飛翔の条件とし ては, 印加電圧を制御させたときと同じ要因と, 更に
ノズル先端に形成されるインクメニスカスの形状効果 を考慮する必要があるものと思われる。

\section{5. 静電誘引形インクジェットのインク飛翔 状況の画像処理}

インク飛翔状況の画像データは 6 bit $の$ 濃度情報と してパーソナルコンピュータに取込んだ。取込んだデ ー夕は比較の対象とする部分の最大值のデータを 1 と

して規格化して解析を行った。

〈5・1〉インク広がり具合について 図 5 (a)の 写真をテレビモニタ画面上に写したものを図 7 に示 す。

インク飛翔状況におけるインク広がり具合の解析 は, 解析ライン(1)に従って行った。解析ライン(1) は, ノズル先端より飛翔するインクジェットに対して垂直 方向に処理する。解析ライン(1)による処理結果を図 8 (a ), (b)に示す。(a)図は印加電圧 $V_{1}=2.5 \mathrm{kV}$, インク静圧 $H=5 \mathrm{~mm}$ 一定の場合を示す。ノズル先端 から飛翔するインク微粒子の密度は, ノズル先端の近 傍において高く記録紙方向へ向かうに従って低下して いる。また，インク飛翔の分布状況は，ノズル近傍に おいて狭く記録紙方向に向かうに従って幅広くなって いる。（b)図は，印加電圧 $V_{2}=2.9 \mathrm{kV}$ と高くした場 合を示す。この特性は $V_{1}$ とほぼ似た現象を示してい る。しかし, 印加電圧が $V_{2}=2.9 \mathrm{kV}$ と高くなると, インク微粒子の密度の低下する位置は記録紙の位置へ と更に伸びていると同時に，インクの広がり具合は狭 くなっている。また, 印加電圧 $V=2.5 \mathrm{kV}$ として, インク静圧 $H=10 \mathrm{~mm}$ とした特性を図 9 に示す。イ ンク飛翔状況は, 図 8 (a) と比較して, インク静圧を 高くすると記録紙の方向へと更に伸びると同時に，イ 


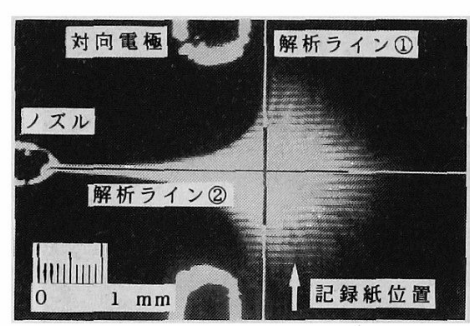

図 7 静電誘引形インクジェットのインク 飛翔 (TV モ二夕画像)

Fig. 7. Flying ink jet on TV monitor.
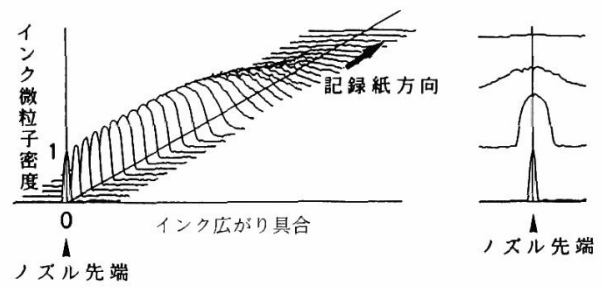

(a) $V_{1}=2.5 \mathrm{kV}, H=5 \mathrm{~mm}$
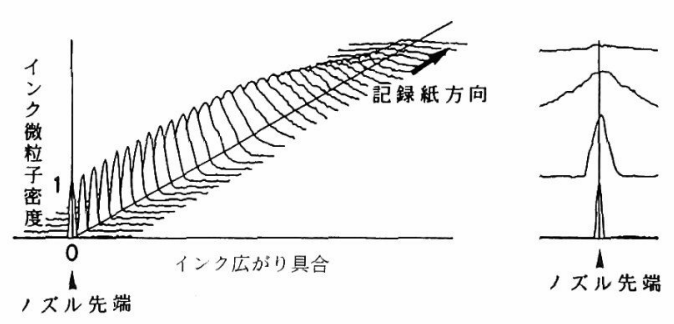

(b) $V_{2}=2.9 \mathrm{kV}, H=5 \mathrm{~mm}$

図 8 印加電圧を制御させた場合のインク 飛翔分布の三次元表示

Fig. 8. Three dimensions of flying ink by controlling applied voltage.

ンク広がり具合は狭くなることが明らかとなった。

記録紙位置における,インク広がり具合を図 10(a)，（b）に示す。ここでの, インク広がり具合 は, (a)図に示すように最大值 $\left(D_{\max }\right)$ の半分 $\left(D_{\max } / 2\right)$ のときの広がり幅 $(W)$ とした。(a)図 は, 印加電圧 $V=2.5 \mathrm{kV}$ 一定として, インク静圧を $H_{1}=5 \mathrm{~mm}$ および $H_{2}=10 \mathrm{~mm}$ と制御させた場合を示 す。この場合のインク広がり具合の変化率は約 $58.2 \%$ あった。また (b)図は, インク静圧 $H=5$ $\mathrm{mm}$ 一定として印加電压を $V_{1}=2.5 \mathrm{kV}$ および $V_{2}=$ $2.9 \mathrm{kV}$ と制御させた場合である。インク広がり具合 の変化率は約 $48.5 \%$ あった。インク飛翔の広がり 具合は, 記録紙位置の方向においてインタ静圧を制御
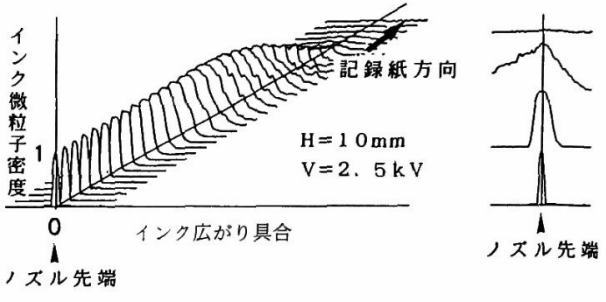

図 9 インク静圧を制御させた場合のインク 飛翔分布の三次元表示

Fig. 9. Three dimensions of flying ink by controlling ink pressure.

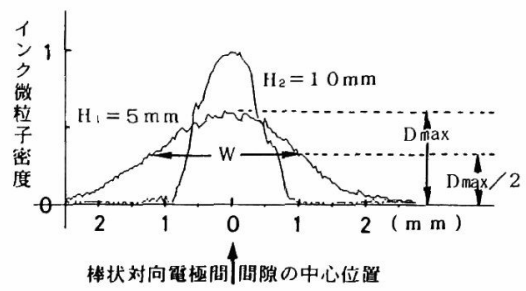

(a) 印加電圧 $V=2.5 \mathrm{kV}$

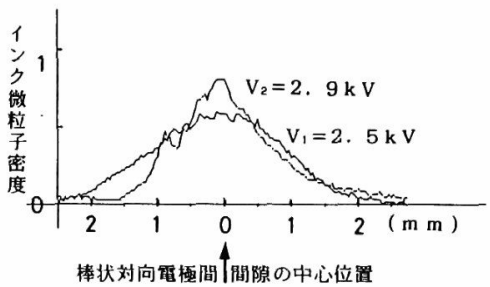

（b） インク静圧 $H=5 \mathrm{~mm}$

図 10 記録紙位置におけるインク広がり具合 Fig. 10. Ink spread condition on the recording position.

させたほうが大きいことが明らかとなった。

〈5・2〉曳糸の状態遷移領域の伸びについて

図 7 の解析ライン(2)について処理した結果を, 図 11(a)，(b)に示す。解析ライン(2)は, ノズル先端か ら飛翔するインクジェットの記録紙方向に対する伸び 具合, つまり, 曳系の状態遷移領域特性について解析 した。(a)図は, 印加電圧 $(V=2.5 \mathrm{kV})$ を一定と してインク静圧を $H=5 \mathrm{~mm}$ および $H=10 \mathrm{~mm}$ と制 御させた場合を示す。

インク静圧の制御による曳系の状態遷移の変化率 は, 約 26\%であった。(b)図は, インク静压 $(H=5$ $\mathrm{mm}$ ) 一定として印加電圧を $V_{1}=2.5 \mathrm{kV}$ および $V_{2}$ $=2.9 \mathrm{kV}$ とした場合を示す。この場合, 曳系状態遷 移領域の変化率は約 $20 \%$ あった。曳系の状態遷移 


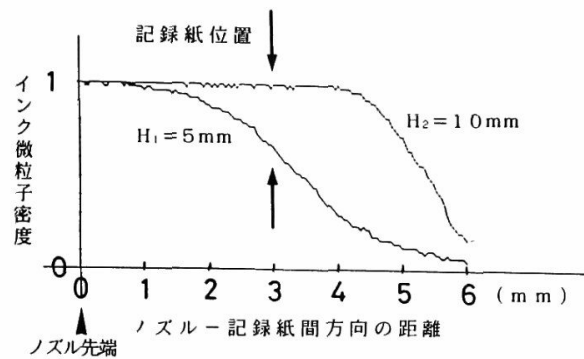

(a) 印加電圧 $V=2.5 \mathrm{kV}$

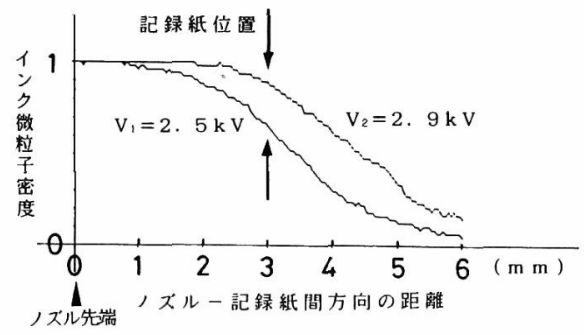

(b) インク静圧 $H=5 \mathrm{~mm}$

図 11 曳系の状態遷移領域特性

Fig. 11. Characteristics of transition state of liquid thread region.

する領域は, 印加電圧が高いほど先端に伸びている。 曳系の状態遷移領域の変化は，インク静圧を制御させ たほうがインクの広がり具合と同様に大きいことが明 らかとなった。

階調画像再生は，記録紙の位置において印加電圧ま たはインク静圧の差によりインク微粒子の密度の差と なり，これが記録濃度の差として表現されるものと考 えられる。

\section{6. 階調画像の再生例}

静電誘引形インクジェットの誘電性インクに用いた 曳系の状態遷移を利用した階調画像の再生例を図 12 に示す。このように，曳系長の位置に対するインク微 粒子化状態の変化を記録濃度の変化とした応用が可能 である。再生例を顕微鏡により判断した結果，曳系領 域は女性像の背景の高濃度部分，毛髪の一部分，洋服 などの再生に，また霧化領域は女性画像背景の低濃度 部分, 額, えり元などの再生に反映されている。

\section{7. むすび}

静電誘引形インクジェットの誘電性インクによるイ

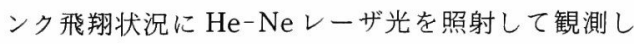
た。

電学論C, 112 巻 9 号, 平成 4 年

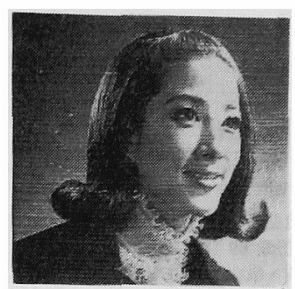

図 12 階調画像再生例

Fig. 12. Example of print.

本方式は, 静電誘引形インクジェット方式による曳 系の状態遷移する状況を，ノズル先端から記録紙に至 るまで平均的な全体像としての観測を可能とした。こ れらの結果, インクの記録位置における広がり具合, また曳糸の状態遷移領域など詳細な振舞いが明らかに なった。記録紙の位置におけるインクの広がり具合 は, 印加電圧およびインク静圧を高く制御するに従つ て狭くなった。曳系の状態遷移領域は, 印加電圧およ びインク静圧を高く制御するに従って, その遷移状態 は更にノズル先端方向へと伸びを示した。

インク静圧の制御は, ノズル先端に形成されるイン クメニスカスの形状効果に大きく影響を与えるものと 思われる。本方式による階調画像再生は, 曳䒺領域扔 よび霧化領域を利用しており, 今回試みた電極位置な どに対して低いインク静圧が適当であった。

曳系の状態遷移は，印加電圧の制御に対してインク 静圧を制御したほうが，その変化率は大きい。しか し, 階調画像の再生には微妙な濃度差が必要であり, 印加電圧を制御したほうが制御方法も簡単であり, 有 利であると思われる。曳系の状態遷移を利用した階調 画像の再生は, 特に霧化時の再生画像が目に見えて不 快感を与えておらず，アパーチャによるインク微粒子 の制御が不要である。

また, 霧化時を利用した画像の再生は, 低濃度領域 の再生に有利である。一般に対向電極の構造は, 円板 状または円筒形で構成され, それに微少な口径のノズ ルからインクを噴出するものが多く見受けられる。こ れらの構造は，インクによる目づまりの原因になりや すいものと思われる。本研究では，棒状電極を対向さ せて対向電極として試みたため，ノズル先端の部分に おいてインクの目づまりなどはなかった。

今後は, インク微粒子径, 曳采径およびインク飛翔 速度などインク飛翔の瞬間的な振舞いの詳細な検討が 必要であると考える。

日ごろ御指導をいただく九州大学工学部平川一美 教授，またレーザ光計測の方法について助言いただい 
た同大工学部村上昭年教授に深く感謝いたします。 (平成 3 年 11 月 25 日受付)

\section{文献}

（1）安院居・清弘・中内：「インクジェットに関する基磷研究」, 画像電学誌, 3, 69 (昭 49)

（2）富田・石橋・横山：「静電形インクジェットプリンタに関す る基礎研究」, 機械学論, B52, 1215 (昭 61)

（3）松尾・黒田・片山・富川・横川・中島：「静電誘引形インク ジェットの He-Neレーザ観測」, 平 2 電気学会大, No. 816

(4) C. H. Hertz \& A. Mansson: "Electric Control of Fluids Jets and it Application to Recording Devices", Rev. Sci Instrum., 43, No. 3, 413 (1972)

(5) E. Stemme \& S. Larsson: "The Piezoelectric Capillary Injector", IEEE Trans. Electr. Devices, ED-20, No. 1, 14 (1973)

(6) C. H. Hertz \& B. Samuelsson: "Ink Jet Printing of Photographic Quality Color Images", SPSE's 4th, p. 150 (1988)

(7) C. H. Hertz \& B. Samuelsson: "Ink Jet Printing of Photo graphic Quality Images", J. Imaging Tech, 15, 141(1989)

（8）松尾・富川・片山・中岛：「インクジェットの状態遷移を利 用した階調画像再生」, 電学論 C, 109, 400 (平元-5)

（9）萩原：「静電気による液体の微粒化 (II)」, 第 21 回秋期灾 用物理学会予稿集, p. 151 (昭 49)

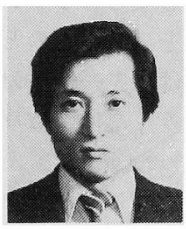

\section{松 尾 一 壽 (正員)}

昭和 23 年 9 月 27 日生。 46 年 3 月福 岡工業大学工学部電子工学科卒業。6 61 年 4 月同大学講師。インクジェットの応 用に関する研究に従事。電子情報通信学 会, IEEE 会員。

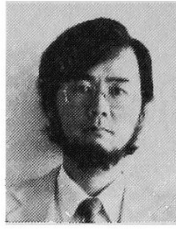

\section{富川武 彦（非会員）}

昭和 20 年 2 月 1 日生。 57 年 3 月静岡 大学大学院博士課程修了。60 年 4 月神 奈川工科大学助教授, 現在に至る。画像 処理の研究に従事。工学博士。電子情報 通信学会, IEEE 会員。

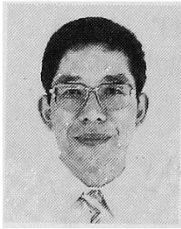

\section{片山年 美 (非会員)}

昭和 19 年 7 月 2 日生。 40 年 3 月福岡 工業短期大学電子工学科卒業。 40 年 4 月福岡工業大学助手, 現在に至る。画像 処理に関する研究に従事。情報処理学 会, 日本経営工学会会員。

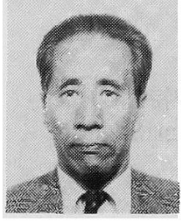

\section{横川京 次 (正員)}

昭和 28 年京都大学工学部電気工学科 卒業。同年神鋼電機 (株) 入社。回転機設 計担当部長, 生産管理部長などを歴任 し, 56 年技術開発本部副部長。6 0 年福 岡工業大学工学部管理工学科教授, 現在に至る。工学博 士。直流電動機とその制御の研究に従事し, 現在は, 主と して経営情報システムの研究に従事。電子情報通信学会, 日本経営工学会会員。 